\title{
ANALISIS KEBERHASILAN USAHA CUCI SEPEDA MOTOR DI KOTA SERANG DILIHAT DARI BESARNYA MODAL, KUALITAS PELAYANAN DAN HARGA
}

\author{
Guli \\ Program Studi Manajemen, Sekolah Tinggi Ilmu Ekonomi Banten (STIE) Banten \\ E-mail: goely67@gmail.com \\ Uli Wildan Nuryanto \\ Program Studi Manajemen, Sekolah Tinggi Ilmu Ekonomi Banten (STIE) Banten \\ E-mail: uli.wildan11@gmail.com
}

\begin{abstract}
Success Analysis of Motorcycle Washing Business in Serang City in View of Capital Amount, Service Quality and Price. The purpose of this research is to determine the magnitude of the effect of capital, service quality and price on the success of motor washing business in Serang City. The analysis is conducted to the owner who engage in motor washing business and consumers who use the services of motor wash. By analyzing the variables partially and together it is expected to obtain the relationship and the magnitude of the correlation between the three factors to the success of the motor washing business in Serang City. This research also explains descriptively economic influence with existing steam motor effort in Serang City. This research uses a survey method with the 32 samples of owner motor washing and 110 consumers. The results of this research are expected to be useful for entrepreneurs who perform motor wash business and useful for the development of science in particular can be a scientific journal and learning framework that can be developed into the future of learning reference.
\end{abstract}

Keywords: Motor Wash, Capital Amount, Service Quality, Price.

Abstrak. Analisis Keberhasilan Usaha Cuci Sepeda Motor di Kota Serang di Lihat Dari Besarnya Modal, Kualitas Pelayanan dan Harga. Tujuan penelitian ini adalah untuk mengetahui besarnya pengaruh dari modal, kualitas pelayanan dan harga terhadap keberhasilan usaha cuci motor di Kota Serang. Analisa dilakukan terhadap pelaku usaha yang menggeluti usaha cuci motor serta konsumen yang menggunakan jasa cuci motor. Dengan menganalisa variabel-variabel tersebut secara parsial dan bersama sama diharapkan dapat diperoleh hubungan dan besarnya korelasi antara ketiga faktor terhadap keberhasilan usaha cuci motor di Kota Serang. Penelitian ini juga menjelaskan secara deskriptif pengaruh ekonomi dengan adanya usaha steam motor yang ada di Kota Serang. Penelitian ini menggunakan metode survey dengan jumlah sampel yang digunakan yaitu sebanyak 32 tempat pencucian motor serta 110 konsumen yang menggunakan jasa cuci motor tersebut. Hasil penelitian ini diharapkan dapat berguna bagi pengusaha yang menggeluti usaha cuci motor serta bermanfaat 
Islamiconomic: Jurnal Ekonomi Islam

Vol.8 No.2 Juli - Desember 2017

$\overline{\text { bagi pengembangan ilmu pengetahuan khususnya dapat menjadi jurnal ilmiah serta }}$ kerangka belajar yang dapat dikembangkan kedepannya menjadi bahan pembelajaran. Kata Kunci: Pencucian Motor, Besarnya Modal, Kualitas Pelayanan, Harga.

\section{Pendahuluan}

Perekonomian Indonesia semakin berkembang dan semakin banyak perubahan dan kemajuan dalam segala aspek, didukung pula dengan terciptanya fasilitas transportasi penghubung dalam bidang automotive yang semakin banyak dan mudah didapatkan, salah satu fasilitas transportasi tersebut adalah kendaraan roda dua atau yang biasa disebut dengan sepeda motor. Menurut Ketua Asosiasi Industri Sepeda Motor Indonesia (AISI), Gunadi Shinduwinata, jumlah sepeda motor di Indonesia pada tahun 2016 mencapai 85 juta unit dibandingkan jumlah populasi masyarakat Indonesia yang sekitar 250 juta jiwa, hal ini dapat diartikan bahwa perbandingan jumlah sepeda motor dengan populasi masyarakat Indonesia adalah satu berbanding tiga. Dengan semakin banyaknya populasi sepeda motor di Indonesia membuka berbagai macam peluang usaha seperti perusahaan lising sepeda motor, perusahaan asuransi sepeda motor, usaha bengkel dan assesoris sepeda motor, sampai kepada usaha steam motor atau yang lebih akrab dikenal dengan usaha cuci motor. Dari berbagai peluang usaha tersebut peluang untuk membuka usaha cuci motor jauh lebih mudah dikarenakan modal yang digunakan masih terhitung ringan dan dapat dijangkau. Dari dasar itulah kita dapat memanfaatkan peluang usaha cuci motor karena faktanya tidak semua orang mau menyisihkan waktunya untuk mencuci motor sendiri. Untuk memulai usaha cuci motor ini kita tidak pelu memiliki keterampilan khusus, cukup hanya menyediakan peralatan yang dibutuhkan untuk menjalankan usaha cuci motor tersebut.

Tidak dapat dipungkiri bahwasanya membuka usaha cuci motor merupakan idaman bagi banyak orang, selain karena menjadi pemilik usaha sendiri dapat mendatangkan berbagai macam keuntungan selain keuntungan materi berupa uang, diantaranya adalah fleksibilitas waktu, dapat membuka lapangan pekerjaan bagi orang lain, membuka hubungan sosial dengan banyak orang termasuk pelanggan dan masih banyak lainnya, namun tentunya usaha cuci motor tidak selamanya berjalan mulus karena banyak didapati usaha cuci motor yang tutup akibat tidak mampu bersaing ataupun karena berbagai alasan lainnya. Untuk itulah diperlukan penelitian 
Guli dan Uli Wildan: Analisis Keberhasilan...

yang mendalam untuk dapat mengenal berbagai aspek yang sangat terkait untuk menunjang keberhasilan usaha cuci motor. Atas dasar itulah penulis berusaha menganalisa beberapa aspek yang mampu berpengaruh terhadap keberhasilan usaha cuci motor, diantaranya adalah besarnya modal, kualitas pelayanan dan harga.

Modal merupakan aspek penting dalam memulai usaha cuci motor, banyak orang yang ingin memulai usaha ini namun terbentur karena tidak memiliki modal, walaupun ada yang mengatakan bahwa modal bukanlah segala-galanya dalam sebuah usaha namun perlu dipahami bahwa modal dalam memulai suatu usaha sangatlah diperlukan. Modal dapat didefiniskan sebagai harta benda yang dapat digunakan untuk menghasilkan sesuatu yang menambah kekayaan (Listyawan Ardi Nugraha, 2011:9). Modal dapat diperoleh dengan berbagai macam cara seperti hasil usaha sendiri dari hasil menabung, mencari modal dari investor, meminjam uang dari Bank ataupun sistem partnership. Usaha cuci motor tidaklah memerlukan banyak biaya, cukup dengan mengeluarkan modal awal sebesar 5 juta rupiah kita sudah dapat membuka usaha cuci motor, dimana modal awal tersebut digunakan sebesar 2 juta untuk membuat kanopi atau pondokan cuci dan sisanya sebesar 3 juta untuk membeli alat Kompressor dan alat steam, sedangkan modal variabel tidaklah terlalu besar, dengan mengeluarkan uang sebesar 400 ribu rupiah setiap bulannya sudah mampu untuk membayar biaya listrik serta kebutuhan sehari-hari lainnya seperti sabun dan lain sebagainya.

Selain modal awal, aspek lainnya yang dapat mempengaruhi keberhasilan cuci motor adalah kualitas pelayanan dimana kepuasan pelanggan akan menjadi pengaruh yang kuat bagi keberhasilan usaha cuci motor. Kualitas pelayanan adalah upaya untuk memenuhi kebutuhan dan keinginan konsumen dan ketepatan pengiriman dalam menyeimbangkan harapan konsumen (Tjiptono, 2010). Dari definisi tersebut dapat di artikan bahwa kualitas pelayanan adalah upaya terhadap pemenuhan harapan dari pelanggan. Kualitas pelayanan dapat diartikan juga sebagai setiap tindakan atau kegiatan yang ditawarkan oleh satu pihak kepada puhak lain yang tidak berwujud (Kotler, 2012). Dari definisi tersebut berarti kualitas pelayanan merupakan sesuatu yang tidak berbentuk konkret sebagai produk namun merupakan jasa atau service yang memiliki nilai dan berpengaruh terhadap pihak tertentu. Kualitas pelayan merupakan aspek yang dianalisa dalam penelitian ini karena besarnya keinginan dan 
Islamiconomic: Jurnal Ekonomi Islam Vol.8 No.2 Juli - Desember 2017

harapan pelanggan untuk menggunakan jasa cuci motor sangat beragam seperti kecepatan waktu pencucian, kebersihan dari pencucian motor dan lain sebagainya.

Faktor keberhasilan lainnya dari usaha cuci motor yang dianalisa adalah harga, dimana harga adalah nilai uang yang harus dikeluarkan untuk mendapatkan produk atau jasa yang diinginkan (Henry Simamora, 2002). Harga merupakan sesuatu yang bernilai bagi kedua belah pihak baik produsen maupun konsumen. Persaingan bisnis saat ini untuk dapat menarik konsumen tidak dapat dilepaskan dari persaingan harga. Biasanya harga yang harus dibayarkan oleh konsumen untuk sekali cuci motor di Kota Serang berkisar antara Rp. 10.000,- sampai dengan Rp. 12.000,- Namun ada juga yang mematok harga lebih dari itu namun tentunya dengan memberikan kualitas pelayan yang sedikit lebih kepada konsumennya.

Penelitian ini bertujuan untuk mengetahui pengaruh besarnya modal terhadap keberhasilan usaha cuci motor di Kota Serang. Pengaruh kualitas pelayanan terhadap keberhasilan usaha cuci motor di Kota Serang. Pengaruh harga terhadap keberhasilan usaha cuci motor di Kota Serang. Pengaruh besarnya modal, kualitas pelayanan dan harga secara bersama-sama terhadap keberhasilan usaha cuci motor di Kota Serang. Penelitian ini dilakukan selama 5 bulan terhitung mulai Januari 2017 sampai dengan Mei 2017, adapun tempat penelitian dilakukan di 4 Kecamatan dari 6 Kecamatan yang ada di Kota Serang, dimana Kota Serang merupakan Ibukota Provinsi Banten.

\section{Kajian Pustaka \\ Konsep UMKM}

Saat ini masih banyak orang yang memandang UMKM sebelah mata, padahal tidak dapat dipungkiri bahwa UMKM adalah salah satu penopang kemajuan perekonomian Nasional yang sangat vital dimana salah satu contohnya adalah saat terjadinya krisis moneter pada tahun 1997 dimana banyak perusahaan besar tumbang satu persatu namun justru bisnis UMKM banyak yang mampu bertahan dan menjadi tulang punggung disaat itu, bahkan menjadi salah satu jenis usaha yang mampu mengentaskan kemiskinan.

Di Indonesia UMKM diatur melalui Undang-undang Nomor 20 Tahun 2008, melalui peaturan tersebut maka dapat dibedakan jenis-jenis usaha mikro, kecil dan menengah berdasarkan atas perbedaan usaha atau jumlah aktiva yang dimiliki. 
Guli dan Uli Wildan: Analisis Keberhasilan...

Secara umum ciri-ciri dari UMKM adalah usaha yang manajemennya berdiri sendiri, modal disediakan sendiri, daerah pemasarannya lokal, aset perusahannya kecil dan jumlah karyawan yang dipekerjakan terbatas dengan berasaskan kebersamaan, ekonomi yang demokratis, kemandirian, keseimbangan kemajuan, berkelanjutan, efisiensi keadilan, serta kesatuan ekonomi nasional.

\section{Konsep Produsen}

Konsep Produsen sebagai pelaku usaha di Indonesia di atur didalam Undangundang Nomor 8 Tahun 1999 pasal 1 ayat 3 dimana yang dimaksud pelaku usaha adalah setiap orang perorangan atau badan usaha baik yang berbentuk badan hukum maupun bukan badan hukum yang didirikan dan berkedudukan dalam wilayah hukum Republik Indonesia, baik sendiri maupun bersama-sama melalui perjanjian menyelenggarakan kegiatan usaha dalam berbagai kegiatan ekonomi.

Menurut Abdulkadir Muhammad (2014), pengusaha diartikan sebagai orang yang menjalankan suatu usaha, baik sendiri maupun dengan bantuan pekerja lainnya. Sedangkan konsep menurut Ikatan Sarjana Ekonomi Indonesia (ISEI) yang dimaksud dengan produsen adalah pelaku usaha yang membuat, memproduksi barang atau jasa dari barang atau jasa lainnya.

Didalam menjalankan usahanya setiap pelaku usha wajib mengikuti peraturan yang berlaku di Indonesia yang diatur kedalam Undang-undang perlindungan Konsumen Nomor 8 Tahun 1999 pasal 6 yang menyebutkan secara detail tentang hak dan kewajiban dari pelaku usaha. Secara singkat hak dari setiap pelaku usaha adalah Hak untuk menerima pembayaran sesuai dengan nilai barang/jasa yang diperdagangkan, Hak untuk mendapat perlindungan hukum dari tindakan konsumen yang beritikad tidak baik, Hak untuk pembelaan diri sepatutnya didalam penyelesaian hukum sengketa konsumen, Hak untuk rehabilitasi nama baik jika kerugian konsumen tidak disebabkan oleh baang/jasa yang diperdagangkan, Hak-hak yang diatur dalam peraturan perundang-undangan lainnya.

Hak-hak pelaku usaha juga diimbangi dengan kewajiban yang harus dilakukan oleh pelaku usaha kepada konsumennya antara lain sebagai berikut : Beritikad baik dalam melakukan kegiatan usahanya, memberikan informasi yang benar, jelas dan jujur mengenai kondisi dan jaminan barang/jasa serta memberikan penjelasan 
Islamiconomic: Jurnal Ekonomi Islam

Vol.8 No.2 Juli - Desember 2017

mengenai cara penggunaan, perbaikan dan pemeliharaan, selanjutnya adalah memperlakukan atau melayanai konsumen konsumen secara benar dan jujur serta tidak diskriminatif, menjamin kualitas barang/jasa yang diperdagangkan sesuai dengan standar kualitas yang berlaku, memberikan kesempatan kepada konsumen untuk menguji dan memberi jaminan atas barang/jasa yang diperdagangkan, memberikan kompensasi atas kerugian konsumen apabila disebabkan oleh penggunaan, pemakaian, pemanfaatan barang/jasa yang diperdagangkan oleh pelaku usaha, memberikan kompensasi apabila barang/jasa yang diterima atau dimanfaatkan konsumen tidak sesuai dengan perjanjian.

\section{Konsep Konsumen}

Menurut Undang-undang perlindungan Konsumen Nomor 8 Tahun 1999 pasal 1 ayat 2 istilah konsumen dibagi menjadi konsumen akhir dan konsumen antara. Konsumen akhir adalah pengguna atau pemanfaatan akhir dari suatu produk, sedangkan konsumen antara adalah konsumen yang menggunakan suatu produk sebagai bagian dari proses produksi lainnya. Sedangkan menurut AZ. Nasution (2013) pengertian Konsumen dibagi menjadi tiga bagian antara lain Konsumen dalam arti umum yaitu pemakai, pengguna atau pemanfaat barang/jasa, Konsumen antara yaitu pemakai, pengguna atau pemanfaat barang/jasa untuk diperdagangkan kembali dengan tujuan komersil, dan yang terakhir adalah Konsumen akhir yaitu pemakai, pengguna atau pemanfaat barang/jasa untuk digunakan sendiri. Sedangkan menurut Kotler (2012) Konsumen adalah semua individu dan rumah tangga yang membeli atau memperoleh barang atau jasa untuk di konsumsi pribadi.

\section{Karakteristik Konsumen}

Karakteristik konsumen menurut Shiffman dan Kanuk (2000) adalah perilaku atau karakter konsumen dalam mencari, membeli, menggunakan, mengevaluasi dan mengambil keputusan terhadap produk/jasa dengan tujuan untuk dapat memuaskan mereka. Sedangkan faktor-faktor yang dapat mempengaruhi perilaku konsumen adalah faktor budaya, sosial, pribadi dan psikologis.

Karakteristik konsumen sangat berpengaruh dalam hal pemilihan produk/jasa karena merupakan pendorong seseorang untuk melakukan pembelian terhadap 
Guli dan Uli Wildan: Analisis Keberhasilan...

barang/jasa. Jika dihubungkan dengan usaha cuci motor maka perilaku konsumen tidak luput dari faktor yang mendorong seseorang untuk mencuci motornya di tempat steam motor namun tentunya dengan berbagai macam alasan yang berbedabeda.

\section{Konsep Jasa}

Jasa menurut Kotler (2012) adalah setiap tindakan atau kinerja yang ditawarkan oleh satu pihak ke pihak yang lain yang secara prinsip tidak berwujud dan tidak menyebabkan perpindahan kepemilikan, produksi jasa dapat terikat atau tidak terikat pada satu produk (fisik). Jasa pada dasarnya adalah seluruh aktivitas ekonomi dengan output selain produk dalam pengertian fisik, dikomsumsi dan diproduksi pada saat bersamaan, memberikan nilai tambah dan secara prinsip tidak berwujud bagi pembeli pertamanya.

Definisi jasa menurut Zeithaml dan Britner (2005) adalah seluruh aktivitas ekonomi dengan output selain produk dalam pengertian fisik, dikonsumsi dan diproduksi pada saat bersamaan, memberikan nilai tambah dan secara prinsip tidak berwujud (intangible) bagi pembeli pertamanya

\section{Konsep Modal}

Menurut Kamus Besar Bahasa Indonesia dalam Listyawan Ardi Nugraha (2011:9) modal usaha adalah uang yang dipakai sebagai pokok (induk) untuk berdagang, melepas uang, dan sebagainya; harta benda (uang, barang, dan sebagainya) yang dapat dipergunakan untuk menghasilkan sesuatu yang menambah kekayaan. Modal dalam pengertian ini dapat di interpretasikan sebagai sejumlah uang yang digunakan dalam menjalankan kegiatan-kegiatan bisnis. Banyak kalangan yang memandang bahwa modal uang bukanlah segala-galanya dalam sebuah bisnis.

Namun perlu dipahami bahwa uang dalam sebuah usaha sangat diperlukan. Yang menjadi persoalan di sini bukanlah penting tidaknya modal, karena keberadaannya memang sangat diperlukan, akan tetapi bagaimana mengelola modal secara optimal sehingga bisnis yang dijalankan dapat berjalan lancar (Amirullah, 2005:7). Menurut Bambang Riyanto (1997:19) pengertian modal usaha sebagai ikhtisar neraca suatu perusahaan yang menggunakan modal konkrit dan modal 
Islamiconomic: Jurnal Ekonomi Islam

Vol.8 No.2 Juli - Desember 2017

abstrak. Modal konkrit dimaksudkan sebagai modal aktif sedangkan modal abstrak dimaksudkan sebagai modal pasif.

\section{Konsep Kualitas Pelayanan}

Pengertian kualitas pelayanan menurut Suwithi dalam Anwar (2002:84) adalah mutu dari pelayanan yang diberikan kepada pelanggan, baik pelanggan internal maupun pelanggan eksternal berdasarkan standar prosedur pelayanan. Kemudian menurut Kotler (2012:25), kualitas pelayanan merupakan totalitas dari bentuk karakteristik barang dan jasa yang menunjukkan kemampuannya untuk memuaskan kebutuhan pelanggan, baik yang nampak jelas maupun yang tersembunyi. Bagi perusahaan yang bergerak di sektor jasa, pemberian pelayanan yang berkualitas pada pelanggan merupakan hal mutlak yang harus dilakukan apabila perusahaan ingin mencapai keberhasilan.

Menurut Fitzsimmons bersaudara dalam Sulastiyono (2011:35-36) menjelaskan bahwa kualitas pelayanan adalah sesuatu yang kompleks, dan tamu akan menilai kualitas pelayanan melalui lima prinsip dimensi pelayanan sebagai ukuranya, yaitu sebagai berikut,

1. Reliabilitas (Reliability) adalah kemampuan untuk memberikan secara tepat dan benar jenis pelayanan yang telah dijanjikan kepada tamu.

2. Responsif(Responsiveness), yaitu kesadaran atau keinginan untuk cepat bertindak membantu tamu dan memberikan pelayanan yang tepat waktu.

3. Kepastian/jaminan (Assurance), adalah pengetahuan dan kesopan santunan serta kepercayaan diri para pegawai. Dimensi assurance memiliki ciri-ciri : kompetensi untuk memberikan pelayanan, sopan dan memiliki sifat respek terhadap tamu.

4. Empati (Empathy), memberikan perhatian individu tamu secara khusus. Dimensi empathy ini memiliki ciri-ciri : kemauan untuk melakukan pendekatan, memberikan perlindungan dan usaha untuk mengerti keinginan, kebutuhan dan perasaan tamu.

5. Nyata (Tangibles), yaitu sesuatu yang nampak atau yang nyata, yaitu : penampilan para pegawai, dan fasilitas-fasilitas pisik, lainnya seperti peralatan dan perlengkapan yang menunjang pelaksanaan pelayanan. 
Guli dan Uli Wildan: Analisis Keberhasilan...

\section{Konsep Harga}

Harga merupakan suatu nilai yang dibuat untuk menjadi patokan nilai suatu barang. Menurut Djasmin Saladin (2001) harga merupakan salat tukar yang digunakan untuk mendapatkan produk atau jasa dengan sejumlah uang. Basu Swastha \& Irawan (2005), harga ialah sesuatu yang dibutuhkan untuk mendapatkan suatu kombinasi antara pelayanan ditambah produk dengan membayar jumlah uang yang sudah menjadi patokan. Menurut Buchari Alma (2002) harga merupakan sebuah nilai yang ditentukan untuk suatu barang maupun jasa yang ditentukan dengan uang. Henry Simamora (2002), harga ialah nilai uang yang harus dikeluarkan untuk mendapatkan produk atau jasa yang diinginkan. - Tjiptono (2002), harga adalah ukuran moneter yang dapat ditukarkan untuk mendapatkan hak atas suatu barang atau pemakaian layanan jasa.

Berdasarkan pengertian harga menurut para ahli diatas dapat disimpulkan bahwa harga adalah nilai uang yang ditentukan secara global yang harus dikeluarkan oleh seseorang untuk mendapatkan suatu produk atau pelayanan jasa yang diinginkan. Peranan harga tak lepas dari proses jual beli suatu produk atau jasa. Harga membantu konsumen untuk menentukan seseorang akan membeli barang atau tidak.

\section{Kerangka Pemikiran}

Dengan melihat kepada variabel penelitian yang di uji antara lain besarnya modal, kualitas pelayanan dan harga maka dapat ditarik hal-hal yang dapat menjadi indikator penunjang dari masing-masing variabel uji tersebut adalah sebagai berikut.

Untuk besarnya modal memiliki indikator-indikator seperti syarat awal untuk memulai usaha, menentukan kestrategisan lokasi usaha, menentukan luas tempat pencucian, menentukan strategi pemasaran, menentukan prasarana penunjang, fasilitas prasarana, pengaruh dalam kemudahan perizinan usaha, motivasi bagi karyawan dalam bekerja. Sedangkan indikator untuk kualitas pelayanan meliputi, keramahan dan kesopanan, kecepatan waktu pencucian, kebersihan hasil cuci, kenyamanan ruang tunggu, keamanan tempat, keteraturan segi antrian, kebersihan 
Islamiconomic: Jurnal Ekonomi Islam Vol.8 No.2 Juli - Desember 2017

dan kerapihan tempat. Adapun infikator untuk harga antara lain keterjangkauan harga, kesesuaian harga dengan kualitas cuci, bonus untuk keterulangan cuci. Sedangkan untuk indikator keberhasilan usaha steam motor dilihat dari adanya peningkatan jumlah konsumen, peningkatan pendapatan usaha, perluasan tempat usaha, perbaikan sarana prasarana, kualitas alat terjaga, titik impas tercapai dan karyawan memiliki loyalitas.

\section{Hipotesis Penelitian}

$\mathrm{H}_{1}$ : Terdapat pengaruh yang signifikan antara besarnya modal terhadap keberhasilan usaha cuci motor yang ada di Kota Serang;

$\mathrm{H}_{2}$ : Terdapat pengaruh yang signifikan antara kualitas pelayanan terhadap keberhasilan usaha cuci motor di Kota Serang;

$\mathrm{H}_{3}$ : Terdapat pengaruh yang signifikan antara harga dengan keberhasilan usaha cuci motor yang ada di Kota Serang.

$\mathrm{H}_{4}$ : Terdapat pengaruh yang signifikan antara besarnya modal, kualitas pelayanan dan harga terhadap keberhasilan usaha cuci motor di Kota Serang.

\section{Metode Penelitian}

Dalam penelitian ini penulis melakukan pengumpulan data yang berupa informasi yang berhubungan dengan masalah yang akan diteliti. hipotesis yang akan digunakan adalah hipotesis bersifat deskriptif dan verifikatif. Penelitian deskriptif adalah penelitian yang dilakukan untuk mengetahui nilai variabel mandiri, baik suatu variabel atau lebih tanpa membuat perbandingan, atau menghubungkan dengan variabel yang lain. Sedangkan yang dimaksud dengan penelitian verifikatif adalah suatu penelitian yang ditujukan untuk menguji teori dan penelitian akan mencoba menghasilkan informasi ilmiah baru yaitu status hipotesa yang berupa kesimpulan apakah suatu hipotesa diterima atau ditolak. Jumlah sampel yang digunakan yaitu sebanyak 32 tempat pencucian motor serta 110 konsumen yang menggunakan jasa cuci motor tersebut. 
Guli dan Uli Wildan: Analisis Keberhasilan...

\section{Hasil Penelitian}

Kota Serang merupakan Ibu Kota Provinsi Banten, Indonesia. Kota Serang dikelilingi oleh Kabupaten Serang disebelah selatan, barat dan timur dan Laut Jawa di sebelah utara. Kota Serang dulunya merupakan bagian dari Kabupaten Serang yang kemudian ditetapkan sebagai Kota otonom pada tanggal 2 November 2007 (www.serangkota.go.id). Populasi Kota Serang sampai dengan tahun 2017 sebesar 521.068 Jiwa. Dengan populasi penduduk yang cukup banyak dan kemajuan perkembangan kota serang yang semakin meningkat menjadikan usaha steam motor sebagai salah satu alternatif usaha yang berkembang subur terlebih dengan meningkatnya jumlah kendaraan roda dua di Kota Serang.

Dari hasil penilitian yang dilakukan oleh penulis dapat di simpulkan bahwa usaha steam motor di Kota Serang merupakan usaha yang dapat membuka lapangan pekerjaan hal ini terbukti dari data yang berhasil dikumpulkan bahwa jumlah pegawai yang bekerja di tempat pencucian motor minimal sebanyak 2 orang dan disetiap kelurahan dapat dipastikan terdapat usaha pencucian motor. Selain membuka lapangan pekerjaan usaha steam motor juga memberikan efek positif berantai terhadap ekonomi dengan meningkatkan taraf pendapatan masyarakat sekitar tempat usaha steam motor, karena biasanya disekitar usaha steam motor akan terdapat usaha mikro seperti warung dan tempat makanan karena biasanya konsumen yang menggunakan jasa usaha steam motor akan menghabiskan waktunya di warung sekitar tempat usaha steam motor sambil menunggu motor mereka selesai di cuci. Besarnya biaya steam motor di Kota Serang relatif terjangkau yaitu berkisar Rp. 10.000,- sampai dengan Rp. 12.000,- dimana variasi harga tersebut dipengaruhi juga oleh lokasi dan besarnya usaha steam motor, karena beberapa tempat yang di sampling oleh peneliti didapatkan usaha steam motor digabung dengan steam mobil sehingga fasilitas tempat pencucian tersebut relatif lebih besar dibandingkan dengan tempat yang hanya membuka steam motor saja. Usaha steam motor yang digabung dengan steam mobil membutuhkan modal yang relatif lebih besar karena fasilitas dan peralatan yang dibutuhkan juga lebih banyak dari tempat yang hanya membuka steam motor, namun disisi lain jumlah karyawan yang dipekerjakan juga lebih banyak 
Islamiconomic: Jurnal Ekonomi Islam

Vol.8 No.2 Juli - Desember 2017

dan bahkan dari salah satu tempat yang penulis jadikan sample ada yang mempekerjakan sebanyak 10 orang karyawan.

Tabel 1. Data Tempat Steam Motor di 4 Kecamatan Kota Serang

\begin{tabular}{|c|c|c|c|c|c|c|c|c|c|c|c|c|c|}
\hline 울 & 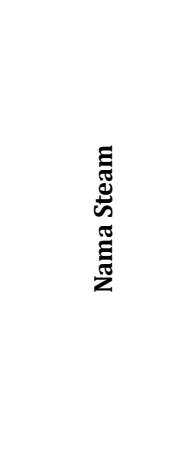 & 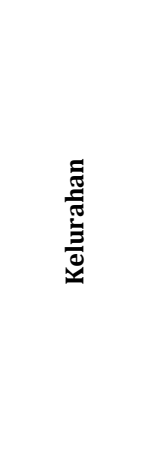 & 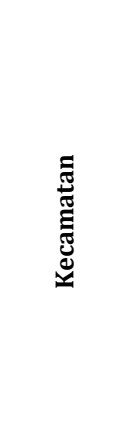 & 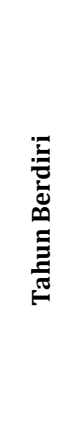 & 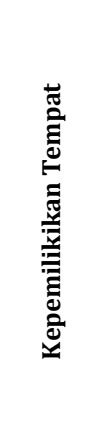 & 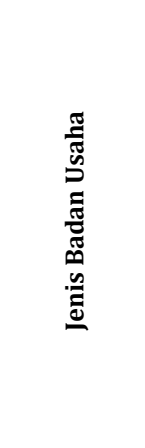 & 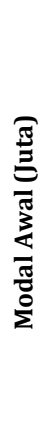 & 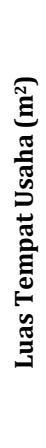 & 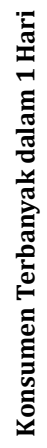 & 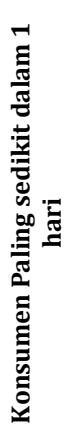 & 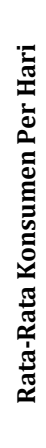 & 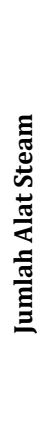 & 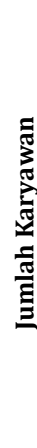 \\
\hline 1 & Adam Steam & $\begin{array}{c}\text { Lontar } \\
\text { Baru }\end{array}$ & Serang & 2015 & Pribadi & Perorangan & 40 & 18 & 15 & 5 & 10 & 1 & 2 \\
\hline 2 & Auto Clean Up & Serang & Serang & 2015 & Pribadi & Perorangan & 20 & 50 & 30 & 5 & 15 & 3 & 4 \\
\hline 3 & $\begin{array}{l}\text { Bang Bross } \\
\text { Steam }\end{array}$ & Sepang & Taktakan & 2016 & Pribadi & Perorangan & 5 & 18 & 30 & 15 & 20 & 2 & 2 \\
\hline 4 & Berkah Jaya & Taktakan & Taktakan & 2014 & Pribadi & Perorangan & 5 & 24 & 25 & 10 & 20 & 2 & 2 \\
\hline 5 & Cipare Steam & Cipare & Cipocok & 2013 & Pribadi & Perorangan & 7 & 30 & 30 & 10 & 15 & 1 & 2 \\
\hline 6 & Delima Jaya & Serang & Serang & 2014 & Pribadi & Perorangan & 10 & 15 & 30 & 10 & 22 & 2 & 3 \\
\hline 7 & Fahran Steam & Banjar Sari & Cipocok & 2016 & Pribadi & Perorangan & 5 & 28 & 22 & 9 & 15 & 2 & 2 \\
\hline 8 & Fajar Wulan & Taktakan & Taktakan & 2016 & Pribadi & Perorangan & 20 & 32 & 20 & 6 & 15 & 1 & 2 \\
\hline 9 & Fani Steam & $\begin{array}{c}\text { Lontar } \\
\text { Baru }\end{array}$ & Serang & 2013 & Pribadi & Perorangan & 5 & 25 & 35 & 10 & 15 & 3 & 2 \\
\hline 10 & Fika Steam & Taktakan & Taktakan & 2016 & Sewa & Perorangan & 10 & 50 & 30 & 10 & 20 & 2 & 3 \\
\hline 11 & $\begin{array}{l}\text { Gesit Auto } \\
\text { Service }\end{array}$ & Cipare & Cipocok & 2015 & Pribadi & Perorangan & 12 & 60 & 30 & 10 & 15 & 2 & 2 \\
\hline 12 & $\begin{array}{l}\text { Lampu Merah } \\
\text { Steam }\end{array}$ & Taktakan & Taktakan & 2011 & Pribadi & Perorangan & 6 & 30 & 30 & 10 & 15 & 2 & 2 \\
\hline 13 & Hilton Steam & Kaujon & Serang & 2016 & Pribadi & Perorangan & 15 & 18 & 20 & 7 & 10 & 2 & 2 \\
\hline 14 & Jimi Jaya & Taktakan & Taktakan & 2015 & Pribadi & Perorangan & 6 & 30 & 20 & 5 & 10 & 1 & 2 \\
\hline 15 & Lansa Steam & Taktakan & Taktakan & 2015 & Pribadi & Perorangan & 60 & $\begin{array}{l}10 \\
00 \\
\end{array}$ & 30 & 10 & 20 & 2 & 5 \\
\hline 16 & Lomo Gowok & Gowok & Cipocok & 2017 & Pribadi & Perorangan & 50 & 50 & 20 & 5 & 17 & 2 & 2 \\
\hline 17 & Long Jaha & Lialang & Taktakan & 2015 & Pribadi & Perorangan & 5 & 72 & 25 & 7 & 15 & 3 & 3 \\
\hline 18 & Mahkota Steam & $\begin{array}{c}\text { Lontar } \\
\text { Baru }\end{array}$ & Serang & 2009 & Pribadi & Perorangan & 5 & $\begin{array}{c}15 \\
0\end{array}$ & 80 & 30 & 50 & 2 & 7 \\
\hline 19 & Obi Steam & Taktakan & Taktakan & 2016 & Pribadi & Perorangan & 10 & 32 & 10 & 2 & 6 & 1 & 2 \\
\hline 20 & Ojan Steam & Kaujon & Serang & 2017 & Pribadi & Perorangan & 10 & 40 & 25 & 10 & 15 & 2 & 2 \\
\hline 21 & Pion Steam & Palima & Curug & 2016 & Pribadi & Perorangan & $\begin{array}{c}10 \\
0 \\
\end{array}$ & $\begin{array}{c}20 \\
0 \\
\end{array}$ & 35 & 10 & 25 & 2 & 10 \\
\hline 22 & Popy Steam & Kamanisan & Curug & 2015 & Pribadi & Perorangan & 5 & 30 & 50 & 3 & 10 & 2 & 5 \\
\hline 23 & Putra Steam & $\begin{array}{l}\text { Banjar } \\
\text { Agung }\end{array}$ & Cipocok & 2016 & Pribadi & Perorangan & 10 & 32 & 25 & 7 & 17 & 1 & 2 \\
\hline 24 & RTC Steam & Serang & Serang & 2016 & Sewa & Perorangan & 6 & 8 & 20 & 8 & 10 & 1 & 2 \\
\hline 25 & Sa'i Steam & Kamanisan & Curug & 2012 & Pribadi & Perorangan & 3 & 15 & 30 & 8 & 15 & 1 & 4 \\
\hline 26 & Sayar Steam & Sayar & Taktakan & 2017 & Pribadi & Perorangan & 5 & 15 & 30 & 15 & 25 & 2 & 2 \\
\hline 27 & Sepang Steam & Sepang & Taktakan & 2017 & Pribadi & Perorangan & 6 & 12 & 40 & 15 & 30 & 2 & 2 \\
\hline
\end{tabular}

152 
Guli dan Uli Wildan: Analisis Keberhasilan...

\begin{tabular}{|c|l|c|c|c|c|c|c|c|c|c|c|c|c|}
\hline 28 & Serang Steam & Serang & Serang & 2016 & Pribadi & Perorangan & 3 & 6 & 20 & 2 & 8 & 1 & 3 \\
\hline 29 & Sumber Rizki & Taktakan & Taktakan & 2017 & Pribadi & Perorangan & 5 & 24 & 20 & 10 & 15 & 1 & 4 \\
\hline 30 & Taktakan Steam & Taktakan & Taktakan & 2017 & Pribadi & Perorangan & 4 & 15 & 20 & 5 & 15 & 1 & 2 \\
\hline 31 & TBL Steam & Sepang & Serang & 2017 & Pribadi & Perorangan & 20 & 16 & 50 & 20 & 30 & 2 & 2 \\
\hline 32 & Yana Steam & Serang & Serang & 2007 & Pribadi & Perorangan & 7 & 50 & 22 & 8 & 15 & 1 & 1 \\
\hline
\end{tabular}

Sumber : Hasil data primer yang telah di kumpulkan

\section{Tahun Berdiri Tempat Steam Motor}

Berdasarkan data primer yang telah di rangkum dalam tabel 1 dapat ditarik kesimpulan dari 32 tempat usaha steam motor, tempat yang paling lama berdiri adalah responden nomor urut 32 dimana pertama kali beroperasi pada tahun 2007 yang artinya tempat steam motor tersebut telah beroperasi hampir 11 tahun, sedangkan yang baru berdiri di tahun 2009, 2011 dan 2012 masing-masing sama sebanyak 1 responden atau 3,125\%, untuk tempat steam yang berdiri pada tahun 2013 dan 2014 masing-masing sama sebanyak 2 responden atau 6.25\% sedangkan untuk tempat steam yang berdiri pada tahun 2015 dan 2017 masing-masing sebesar 7 responden atau $21.875 \%$ dan yang paling terbanyak adalah yang berdiri pada tahun 2016 yaitu sebanyak 10 responden atau $31.25 \%$.

\section{Kepemilikan Tempat dan Jenis Badan Usaha}

Berdasarkan data primer yang telah dikumpulkan pada tabel 1 dapat disimpulkan dari 32 tempat usaha steam motor yang dijadikan sample, sebanyak 31 tempat dimiliki sendiri yang artinya usaha tempat steam motor menggunakan lahan sendiri tanpa harus menyewa dan mayoritas bergabung dengan tempat tinggal pemilik, sedangkan 1 tempat steam motor memilih untuk menyewa tempat dengan alasan lokasi rumah tidak berada di pinggir jalan dan sempit sehingga harus menyewa tanah kosong yang ada di pinggir jalan raya untuk dijadikan tempat usaha steam motor. Untuk status badan hukum dan kepemilikan dari usaha steam motor seluruh responden atau $100 \%$ responden membentuk usaha steam motor mereka sebagai usaha perorangan atau pribadi, hal ini dikarenakan modal yang dibutuhkan tidak terlalu besar dan jenis usaha mereka termasuk kedalam UMKM. 


\section{Besarnya Modal}

Untuk memulai usaha steam motor diperlukan modal awal yang dipergunakan sebagai fixed cost seperti pembuatan kanopi untuk tempat pencucian, membeli kompresor dan lainnya, namun dari hasil penelitian biaya tersebut tidak terlalu besar karena mayoritas responden membuat usaha steam motor mereka di lokasi rumah sehingga tidak perlu membuat infrastruktur lagi seperti kanopi jadi modal awal hanya digunakan untuk membeli peralatan steam dan kebutuhan operasional lainnya, hal ini digambarkan dengan data sebanyak 12 responden mengeluarkan modal awal dibawah 5 juta rupiah atau sekitar 38\% dari total 32 responden.

Untuk tempat steam motor yang mengeluarkan modal awal 6-10 juta rupiah sebanyak 11 responden atau 34\% dari total populasi, sedangkan yang mengeluarkan modal awal 11-20 juta rupiah sebanyak 5 responden atau sekitar 16\%, untuk tempat usaha steam motor yang mengeluarkan modal awal diatas 20 sampai 50 juta rupiah sebanyak 2 responden atau 6.3\%, sedangkan yang mengeluarkan modal diatas 50 sampai 100 juta rupiah sebanyak 2 responden atau 6.3\% dari populasi.

Perbedaan besarnya modal awal yang digunakan bergantug kepada jenis tempat yang dibangun apakah semi permanen hanya dengan menggunakan terpal dan kayu atau non permanen dimana tempat usaha menggunakan bangunan kanopi tanpa batasan tembok dengan lingkungan sekitar dan yang terakhir adalah tempat steam motor permanen dimana tempat usaha dibuat dari kanopi struktur besi dan bata serta diberi pagar batasan dengan lingkungan sekitar, untuk tempat ini biasanya selain menjalankan usaha steam motor juga menjalankan usaha pencucian mobil sehingga modal awal yang digunakan juga cukup besar. Selain itu juga besarnya modal awal dipengaruhi oleh luas tempat usaha steam motor yang dibuat.

\section{Luas Tempat Usaha}

Berdasarkan hasil penelitian dilapangan yang telah dirangkum dalam tabel $1 \mathrm{di}$ dapatkan kesimpulan bahwa untuk membuka temat usaha steam motor tidak membutuhkan luas tempat yang besar, hal ini digambarkan dari total 32 responden tempat steam motor sebanyak 19 responden atau 59.375\% memiliki luas tempat usaha kurang dari $30 \mathrm{~m}^{2}$ sedangkan yang memiliki luas tempat usaha diatas 30-60 $\mathrm{m}^{2}$ 
Guli dan Uli Wildan: Analisis Keberhasilan...

sebanyak 9 responden atau 28.125\%, untuk tempat usaha steam motor yang memiliki luas tempat diatas $60-150 \mathrm{~m}^{2}$ sebanyak 2 responden atau $6.25 \%$ dan yang terakhir tempat steam yang luas areanya diatas $150 \mathrm{~m}^{2}$ sebanyak 2 responden atau $6.25 \%$. untuk tempat usaha yang memiliki luas tempat usaha diatas $150 \mathrm{~m}^{2}$ merupakan tempat usaha steam motor sekaligus juga steam mobil sehingga luas tempat usaha membutuhkan area yang lebih luas bahkan terdapat 1 responden yang memiliki luas area $1000 \mathrm{~m}^{2}$.

\section{Jumlah Konsumen}

Berdasarkan tabel 1 didapatkan jumlah konsumen terbanyak tiap harinya dari masing-masing tempat usaha sangat bervariasi mulai dari 10 konsumen sampai 80 konsumen, sedangkan jumlah konsumen paling sedikit dalam satu harinya juga bervariasi mulai dari 50 konsumen sampai dengan hanya 2 konsumen dan untuk rata-rata konsumen per harinya juga bervariasi mulai dari yang hanya 6 konsumen sampai 50 konsumen. Banyaknya konsumen ini bergantung kepada luasnya area tempat usaha dan lokasi tempat usaha serta posisi atau letak strategisnya tempat usaha tersebut.

\section{Jumlah Karyawan}

Dari total 32 stempat steam motor yang dijadikan sample oleh penulis didapatkan banyaknya karyawan dari masing-masing tempat steam sangatlah bervariasi, mulai dari yang hanya 1 orang dimana dikerjakan langsung oleh pemilik tempat usaha sampai kepada yang mempekerjakan 10 orang karyawan. Hal ini bergantung kepada besar kecilnya tempat usaha dan jumlah konsumen yang ada. Untuk total jumlah karyawan yang bekerja di 32 responden tempat usaha steam didapatkan total sebanyak 92 orang karyawan, hal ini cukup menggembirakan dikarenakan usaha steam motor yang secara basic masuk kedalam kelompok UMKM mampu menyerap jumlah tenaga kerja yang cukup sigifikan banyak. Kenyataan yang didapatkan dilapangan ini menggambarkan bahwasanya UMKM masih menjadi salah satu tulang punggung dalam membuka peluang lapangan pekerjaan dan mendongkrak perekonomian masyarakat khususnya yang ada di Kota Serang Provinsi Banten. 


\section{Harga Jasa Steam Motor}

Untuk harga jasa steam motor di Kota Serang yang diamati oleh penulis selama melakukan penelitian dilapangan tidak terlalu bervariasi hal ini dikarenakan harga jasa steam motor memang sudah menjadi pasaran yaitu sebesar Rp.10.000,- untuk sekali pencucian namun ada 2 tempat atau responden yang harganya lebih tinggi yaitu sebesar Rp. 12.000,- hal ini bergantung kepada si pemilik tempat usaha dalam penentuan harga dan untuk tempat steam motor yang harganya diatas harga pasaran adalah tempat steam motor yang menggunakan fasilitas lebih seperti menggunakan cuci salju dan tempat ini tidak hanya menyediakan jasa pencucian motor saja namun jasa pencucian mobil juga.

\section{Klasifikasi Jenis Kelamin Konsumen}

Berdasarkan hasil penelitian untuk variabel jenis kelamin konsumen yang menggunakan jasa steam motor didapatkan hasil sebagai berikut, Jumlah konsumen dengan jenis kelamin laki-laki sebanyak 78 orang atau $70.9 \%$ dari total 110 sample konsumen, sedangkan konsumen dengan jenis kelamin perempuan sebanyak 32 orang atau $29.1 \%$.

\section{Klasifikasi Usia Responden Konsumen}

Dari hasil olah data primer didapatkan bahwa total konsumen yang berusia dibawah 20 tahun sebanyak 20 orang atau 18.2\% dari total sample, sedangkan total konsumen yang usianya diatas $20-30$ tahun sebanyak 76 orang atau $69.1 \%$ dari total sample. Konsumen yang usianya diatas 30-40 tahun sebanyak 9 orang atau $8.2 \%$ dari total sample sedangkan konsumen yang usianya diatas 40 tahun sebanyak 5 orang atau $4.5 \%$.

Hasil ini cukup menarik jika dilihat dari mayoritas konsumen yang menggunakan jasa steam motor adalah konsumen yang berusia 20-30 tahun padahal jika kita bandingkan antara interval usia tersebut dengan kondisi fisik adalah usia muda yang masih kuat untuk mencuci motornya sendiri namun banyak faktor lain yang akhirnya menggunakan jasa steam motor diantaranya adalah gaya hidup dan keterbatasan waktu yang dimiliki. 
Guli dan Uli Wildan: Analisis Keberhasilan...

\section{Hasil Uji Instrument}

\section{Uji Validitas}

Uji validitas digunakan untuk mengukur tingkat kesahihan suatu instrumen atau perubah. Teknik analis butir instrumen untuk menguji validitas empiric menggunakan rumus Pearson Correlation Product Moment, dengan membandingkan nilai $r_{h i t u n g}$ dengan $r_{\text {tabel }}$ atau dikatakan valid apabila nilai korelasinya diatas 0,3. Perhitungan validitas menggunakan SPSS, dengan melihat correted item totalcorrelation. Dari hasil uji validitas didapatkan untuk masing-masing item indicator valid. Adapun hasil perhitungan terlihat pada tabel 2 berikut :

Tabel. 2. Uji Validitas

\begin{tabular}{|c|c|c|c|}
\hline No & $r_{\text {hitung }}$ & $r_{\text {Tabel }}$ & Keterangan \\
\hline \multicolumn{4}{|c|}{ Besarnya Modal (X1) } \\
\hline $\mathrm{X} 1 \_1$ & 0.633 & 0.1874 & Valid \\
\hline $\mathrm{X} 1 \_2$ & 0.460 & 0.1874 & Valid \\
\hline $\mathrm{X} 1 \_3$ & 0.595 & 0.1874 & Valid \\
\hline $\mathrm{X} 1 \_4$ & 0.651 & 0.1874 & Valid \\
\hline X1_5 & 0.695 & 0.1874 & Valid \\
\hline X1_6 & 0.573 & 0.1874 & Valid \\
\hline $\mathrm{X} 1 \_7$ & 0.560 & 0.1874 & Valid \\
\hline \multicolumn{4}{|c|}{ Kualitas Pelayanan (X2) } \\
\hline X2_1 & 0.609 & 0.1874 & Valid \\
\hline $\mathrm{X} 2 \_2$ & 0.578 & 0.1874 & Valid \\
\hline $\mathrm{X} 2 \_3$ & 0.634 & 0.1874 & Valid \\
\hline $\mathrm{X} 2 \_4$ & 0.682 & 0.1874 & Valid \\
\hline X2_5 & 0.656 & 0.1874 & Valid \\
\hline X2_6 & 0.594 & 0.1874 & Valid \\
\hline $\mathrm{X} 2 \_7$ & 0.724 & 0.1874 & Valid \\
\hline $\mathrm{X} 2 \_8$ & 0.726 & 0.1874 & Valid \\
\hline X2_9 & 0.711 & 0.1874 & Valid \\
\hline $\mathrm{X} 2 \_10$ & 0.580 & 0.1874 & Valid \\
\hline \multicolumn{4}{|c|}{ Harga (X3) } \\
\hline X3_1 & 0.741 & 0.1874 & Valid \\
\hline X3_2 & 0.767 & 0.1874 & Valid \\
\hline X3_3 & 0.837 & 0.1874 & Valid \\
\hline X3_4 & 0.705 & 0.1874 & Valid \\
\hline \multicolumn{4}{|c|}{ Keberhasilan Usaha (Y) } \\
\hline Y_1 & 0.625 & 0.1874 & Valid \\
\hline Y_2 & 0.600 & 0.1874 & Valid \\
\hline Y_3 & 0.647 & 0.1874 & Valid \\
\hline
\end{tabular}


Islamiconomic: Jurnal Ekonomi Islam

Vol.8 No.2 Juli - Desember 2017

\begin{tabular}{llll}
\hline Y_4 & 0.716 & 0.1874 & Valid \\
\hline Y_5 & 0.704 & 0.1874 & Valid \\
\hline Y_6 & 0.652 & 0.1874 & Valid \\
\hline Y_7 & 0.747 & 0.1874 & Valid \\
\hline
\end{tabular}

\section{Uji Reliabilitas}

Uji reliabilitas digunakan untuk mengukur konsistensi suatu alat ukur dalam penelitian (Sugiono, 2012). Kehandalan (reliability) instrumen dan pertanyaan ditentukan dengan menggunakan rumus AlphaCronbach. Instrumen yang digunakan dalam variabel tersebut dikatakan andal (reliabel) apabila memiliki cronbach alpha lebih besar dari 0,6. Adapun hasil perhitungan yang didapat dengan menggunakan program SPSS untuk masing-masing variabel dapat dilihat pada table berikut :

Tabel. 3. Hasil Uji Reliabilitas

\begin{tabular}{|c|c|c|c|}
\hline Variabel & $\begin{array}{l}\text { Cronbach's } \\
\text { Alpha }\end{array}$ & Standar & Status \\
\hline Besarnya Modal $\left(\mathrm{X}_{1}\right)$ & 0,695 & 0,6 & Valid \\
\hline Kualitas Pelayanan $\left(\mathrm{X}_{2}\right)$ & 0,846 & 0,6 & Valid \\
\hline Harga $\left(\mathrm{X}_{3}\right)$ & 0,756 & 0,6 & Valid \\
\hline Keberhasilan Usaha (Y) & 0,794 & 0,6 & Valid \\
\hline
\end{tabular}

\section{Uji Asumsi Klasik Model Regresi}

\section{Uji Normalitas dan Linearitas}

Uji Normalitas dimaksudkan untuk mengetahui apakah residual yang diteliti berdistribusi normal atau tidak. Deteksi adanya normalitas adalah dengan melihat penyebaran data (titik) pada sumbu diagonal dari grafik. Uji normalitas data merupakan syarat yang harus terpenuhi sebelum dilakukan analisis korelasi. Oleh karena itu, masing-masing variabel bebas dan variabel terikat diuji normalitas datanya dengan menggunakan Grafik Histogram dan Normal P-P Plot of Regression Standardized Residual. Berdasarkan hasil perhitungan dengan menggunakan bantuan program SPSS 22 diperoleh hasil uji normalitas data sebagaimana ditunjukkan pada berikut berikut ini: 


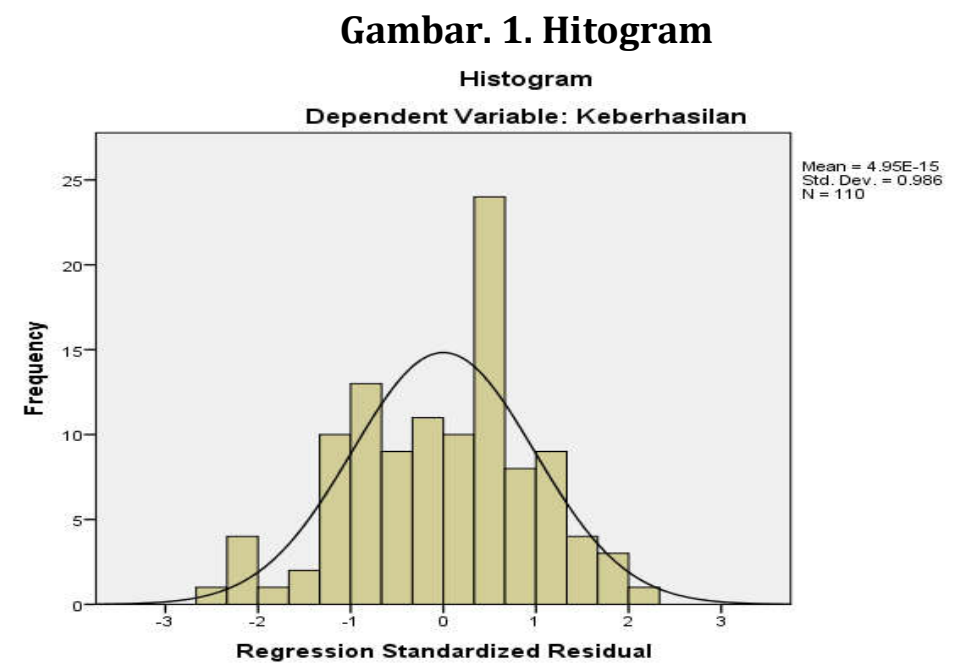

Dari gambar diatas dapat dilihat bahwa garis normal membentuk lonceng dengan kemiringan dan keruncingan yang normal sehingga dapat disimpulkan dengan menggunakan Histogram bahwa distribusi residual data bersifat normal, sebagai pembanding diuji juga menggunakan Normal P-P Plot of Regression Standardized Residual dan hasilnya seperti pada gambar berikut ini :

\section{Uji Autokorelasi}

Persyaratan lainnya sebelum menguji data menggunakan statistic parametris dengan regresi linear berganda adalah dengan uji Autokorelasi yaitu dengan menggunakan metode Durbin Watson (DW Test) yang bertujuan untuk mengetahui ada atau tidaknya penyimpangan asumsi klasik pada satu pengamatan dengan pengamatan lain dimana model yang ideal adalah tidak adanya autokorelasi dengan membandingkan nilai DW hitung terhadap nilai dU tabel. Adapun hasil pengujian didapatkan nilai DW sebesar 1.966 sedangkan nilai dU tabel sebesar 1.7651. pengambilan keputusan terhadap model yang dianggap tidak autokorelasi adalah jika nilai dU hitung berada diantara $\mathrm{dU}<\mathbf{D W}_{\text {Hitung }}<4$-dU. Dari hasil tersebut dapat disimpulkan bahwa nilai DW berada pada nilai toleransi sehingga dapat disimpulkan bahwa model bebas autokorelasi. 


\section{Uji Multikolinearitas}

Uji asumsi klasik Multikolinearitas bertujuan untuk mengetahui hubungan yang sempurna antara variabel bebas dalam model regresi. Gejala multikolinearitas dapat dilihat bila nilai Tolerance dan Varian Inflation Factor (VIF). Apabila hasil pengujian menghasilkan nilai Tolerance diatas 0.1 dan nilai VIF dibawah 10 menandakan bahwa model tidak mengalami Mulikolinearitas (Ghozali, 2012). Dari hasil pengolahan data didapatkan nilai VIF untuk masing-masing variabel bebas sebesar 1.001, 5.212 dan 5.213 yang berarti berada dibawah 10 sehingga dapat disimpulkan bahwa model regresi tidak mengalami Multikolinearitas.

\section{Uji Heteroskedastisitas}

Uji Heteroskedastisitas adalah uji untuk mengetahui apakah ada ketidaksamaan varian dari residual untuk semua pengamatan pada model regresi linear jika asumsi Heteroskedastisitas tdak terpenuhi maka model regresi dinyatakan tidak valid sebagai alat peramalan. Pada pengujian ini digunakan metode Scatterplot yang dihasilkan dari output program SPSS 22 dimana jika pada gambar menunjukan titiktitik menyebar secara acak serta tersebar baik diatas angka 0 maupun sumbu Y maka hal ini dapat disimpulkan bahwa model tidak mengalami heteroskedastisitas (Ghozali, 2012).

\section{Gambar 2. Scatterplot}

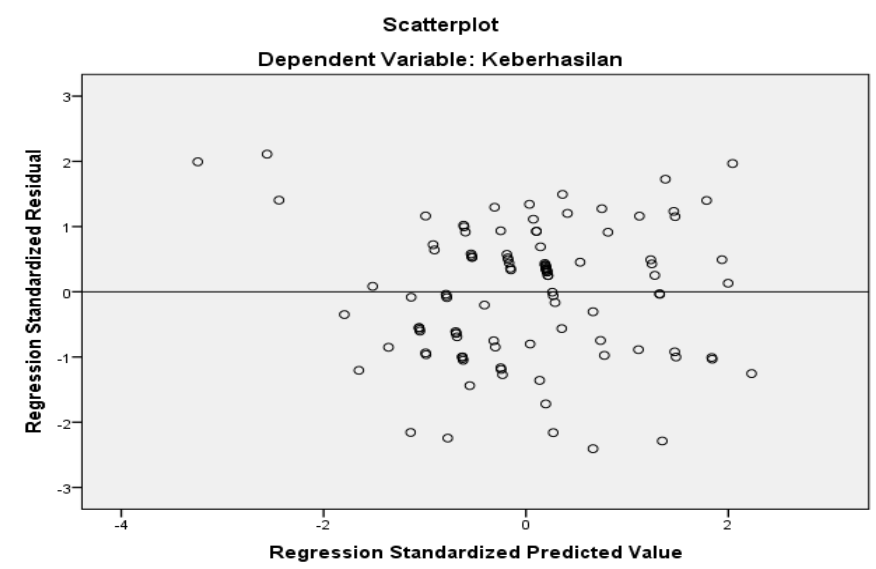

Dari grafik diatas dapat terlihat bahwa titik-titik yang menyebar secara acak tidak membentuk suatu pola tertentu yang jelas serta tersebar baik diatas maupun 
Guli dan Uli Wildan: Analisis Keberhasilan...

bawah angka 0 (nol) pada sumbu Y, dimana hal tersebut menggambarkan tidak terjadinya penyimpangan heteroskedastisitas pada model regresi yang dibuat.

\section{Uji Regresi Linear Berganda}

Dari hasil uji asumsi diatas dapat disimpulkan bahwa model regresi yang akan dijadikan persamaan memiliki model normal terbukti dengan uji asumsi klasik yang dihasilkan bebas dari bentuk penyimpangan yang ada. Adapun analisis regresi digunakan untuk menguji hipotesis tentang pengaruh secara simultan variabel bebas terhadap variabel terikat. Dari hasil tabel dapat ditarik kesimpulan bahwa persamaan model regresinya adalah sebagai berikut :

$$
\begin{aligned}
& Y=a+b_{1} X_{1}+b_{2} X_{2}+b_{3} X_{3} \\
& Y=-1.171+0.013 X_{1}+1.054 X_{2}-0.832 X_{3} \\
& \text { Keterangan : } \\
& Y \quad=\text { Keberhasilan Usaha Steam Motor } \\
& X_{1} \quad=\text { Modal } \\
& X_{2} \quad=\text { Kualitas Pelayanan } \\
& X_{3} \quad=\text { Harga }
\end{aligned}
$$

Dari persamaan tersebut dapat ditarik kesimpulan sebagai berikut :

a. Variabel Modal dan Kualitas pelayanan memiliki koefisien positif terhadap variabel keberhasilan usaha steam motor sedangkan unuk variabel harga memiliki koefisien yang negatif terhadap variabel keberhasilan usaha steam motor.

b. Koefisien modal memberikan nilai positif sebesar 0.013 yang berarti jika variabel modal semakin baik dengan asumsi variabel lain tetap maka variabel keberhasilan usaha steam motor akan mengalami peningkatan.

c. Koefisien kualitas pelayanan menghasilkan nilai sebesar 1.054 yang berarti bahwa jika kualitas pelayanan semakin tinggi dengan asumsi variabel lain tetap maka variabel keberhasilan usaha steam motor akan mengalami peningkatan. 
d. Koefisien harga menghasilkan nilai sebesar -0.832 yang berarti jika variabel harga semakin tinggi dengan asumsi variabel lain tetap maka variabel keberhasilan usaha steam motor akan mengalami penurunan. Namun sebaliknya jika nilai variabel harga semakin rendah maka akan meningkatkan nilai variabel keberhasilan usaha steam motor.

\section{Uji Hipotesis Secara Simultan (Uji F)}

Pada penelitian ini digunakan Uji F untuk menguji hipotesi yang dibuat, dimana nilai F pengujian didapatkan Pengujian pengaruh variabel bebas secara bersamasama terhadap variabel terikat sebesar 1293.047 dengan nilai Signifikansi sebesar 0.000. dari hasil tersebut dapat disimpulkan bahwa nilai Sig $<0.05$ sehingga Ho ditolak dan Ha diterima yang atinya ada pengaruh yang signifikan antara modal, kualitas pelayanan dan harga terhadap keberhasilan usaha steam motor yang ada di Kota Serang.

\section{Koefisien Determinasi $\left(\mathbf{R}^{2}\right)$}

Koefisien determinasi merupakan besaran yang menunjukan besarnya variasi variabel dependen yang dapat dijelaskan oleh vaiabel independennya. Dengan kata lain semakin besar nilai koefisien determinasi maka pengaruh variabel-variabel bebas terhadap variabel terikat semakin besar sebaliknya jika semakin nilai koefisien determinasi semakin kecil maka pengaruh variabel-variabel bebas terhadap variabel terikat semakin kecil. Dari hasil pengolahan data menggunakan SPSS didapatkan hasil tabel R Square sebesar 0.973 sehingga nilai koefisien determinasi yang didapatkan sebesar 97.3\% maka dapat disimpulkan bahwa pengaruh variabel bebas berupa modal, kualitas pelayanan dan harga memiliki pengaruh sebesar $97.3 \%$ terhadap keberhasilan usaha steam motor yang artinya pengaruh dari ketiga variabel bebas tersebut sangat tinggi.

\section{Uji Hipotesis Secara Parsial (Uji t)}

Pada penelitian ini hipotesis diuji juga dengan menggunakan uji $t$ dengan menggunakan Uji Parsial dimana pengujian dilakukan dengan melihat nilai Signifikansi yang dihasilkan. Jika nilai Signifikansi yang dihasilkan dibawah 0.05 maka 
Guli dan Uli Wildan: Analisis Keberhasilan...

$\overline{\text { hipotesis nol ditolak namun jika nilai Signifikansi lebih dari } 0.05 \text { maka hipotesis nol }}$ diterima.

\section{Uji Hipotesis Parsial Variabel Modal ( $\left.\mathrm{X}_{1}\right)$}

Dari hasil pengolahan data didapatkan nilai Signifikansi untuk variabel Modal $\left(\mathrm{X}_{1}\right)$ sebesar 0.396 yang berarti nilai tersebut diatas 0.05 sehingga dapat disimpulkan bahwa Ho diterima dan Ha di tolak yang artinya variabel modal tidak berpengaruh secara signifikan terhadap variabel keberhasilan usaha (Y) steam motor jika diuji secara parsial.

\section{Uji Hipotesis Parsial Variabel Kualitas Pelayanan $\left(\mathrm{X}_{2}\right)$}

Dari hasil pengolahan data didapatkan nilai Signifikansi untuk variabel Kualitas pelayanan $\left(\mathrm{X}_{2}\right)$ sebesar 0.000 yang berarti nilai tersebut dibawah 0.05 sehingga Ho ditolak dan Ha diterima yang artinya variabel kualitas pelayanan berpengaruh signifikan terhadap variabel keberhasilan usaha (Y) steam motor di Kota Serang jika di uji secara parsial.

\section{Uji Hipotesis Parsial Variabel Harga $\left(\mathrm{X}_{3}\right)$}

Dari hasil pengolahan data didapatkan nilai Signifikansi untuk variabel Harga $\left(\mathrm{X}_{3}\right)$ sebesar 0.000 yang berarti nilai tersebut dibawah 0.05 sehingga Ho ditolak dan Ha diterima yang artinya variabel Harga berpengaruh signifikan terhadap variabel keberhasilan usaha (Y) steam motor di Kota Serang jika di uji secara parsial.

\section{Pembahasan}

Berdasarkan hasil penelitian secara statistik dapat dilihat dengan jelas bahwa usaha pencucian steam motor dikota serang merupakan usaha yang dapat mendongkrak ekonomi khususnya bagi masyarakat yang memiliki modal tidak terlalu banyak untuk membuka suatu usaha dimana 38\% tempat usaha steam motor memulai usahanya hanya dengan modal awal sebesar 5 juta rupiah sedangkan 34\% tempat usaha steam motor memulai usahanya dengan modal 6-10 juta rupiah. Selain itu juga luas tempat usaha yang dibutuhkan tidak terlalu luas hal ini dapat disimpulkan bahwa sebanyak 59.375\% tempat usaha steam motor memiliki luas tempat usaha dibawah $30 \mathrm{~m}^{2}$ yang berarti dengan luas tersebut banyak tempat 
Islamiconomic: Jurnal Ekonomi Islam Vol.8 No.2 Juli - Desember 2017

alternatif yang dapat digunakan seperti mislanya halaman rumah, sedangkan untuk prospek konsumen dapat dilihat bahwa rata-rata konsumen paling sedikit dalam satu harinya bervariasi mulai dari 2 konsumen sampai 50 konsumen sedangkan untuk konsumen terbanyak mulai dari 10 konsumen sampai dengan 80 konsumen, hal ini menandakan bahwa prospek usaha steam motor secara materi cukup menjanjikan. Dari data yang berhasil dikumpulan bahwa sebanyak $31.25 \%$ tempat usaha steam motor dibuka pada tahun 2016 sedangkan 21,875\% dibuka masing-masing pada tahun 2015 dan tahun 2017, adapun tempat usaha steam motor yang paling lama beroperasional adalah pada tahun 2007 sebanyak satu tempat usaha steam motor sedangkan sisanya berkisa antara tahun 2009, 2011 dan 2011.

Usaha pencucian steam motor juga berpotensi menyerap lapangan pekerjaan hal ini dapat dilihat dari 32 responden tempat steam motor yang di sampling oleh peneliti dapat menampung sebanyak 92 karyawan. Hasil tersebut cukup menggembirakan terlebih saat ini lapangan pekerjaan yang ada sangat terbatas dan kompetetif khususnya bagi masyarakat yang memiliki tingkat pendidikan formal tidak terlalu tinggi tentunya akan sedikit lebih sulit untuk dapat bersaing dalam mendapatkan pekerjaan formal.

Hasil uji Hipotesis variabel modal secara parsial terhadap variabel keberhasilan usaha steam motor menunjukan hasil tidak adanya pengaruh signifikan antara variabel modal terhadap variabel keberhasilan usaha steam motor hal ini dapat dilihat dimana nilai Signifikansi dari variabel modal lebih besar dari 0.05 .

Hasil Uji Hipotesis variabel kualitas pelayanan secara parsial terhadap variabel keberhasilan usaha steam motor menunjukan hasil adanya pengaruh signifikan antara variabel kualitas pelayanan dengan variabel keberhasilan usaha steam motor hal ini dapat dilihat dari nilai Signifikansi variabel kualitas pelayanan lebih kecil dari 0.05 .

Untuk hasil uji hipotesis variabel Harga secara parsial terhadap variabel keberhasilan usaha steam motor menunjukan hasil adanya pengaruh yang signifikan antara variabel harga dengan variabel keberhasilan usaha steam motor hal ini dapat dilihat dari nilai signifikansi variabel harga lebih kecil dari 0.05 .

Sedangkan hasil uji Hipotesis secara simultan antara variabel-variabel bebas yaitu modal, kualitas pelayanan dan harga terhadap keberhasilan usaha steam motor 164 
Guli dan Uli Wildan: Analisis Keberhasilan...

didapatkan adanya pengaruh signifikan hal ini dapat dilihat dari nilai signifikansi yang didapatkan lebih kecil dari 0.05 .

\section{Kesimpulan}

Dari pembahasan yang telah diuraikan maka dapat disimpulkan sebagai berikut:

1. Hasil pengujian hipotesis variabel modal secara parsial terhadap variabel keberhasilan usaha steam motor didapatkan tidak adanya pengaruh yang signifikan antara variabel modal dengan keberhasilan usaha steam motor, hal ini dapat dibuktikan dengan hasil Signifikansi sebesar 0.396 variabel modal (X1) terhadap keberhasilan usaha dimana nilai tersebut lebih besar dari 0.05 yang berarti penelitian ini Ho diterima dan Ha ditolak.

2. Hasil pengujian hipotesis variabel kualitas pelayanan secara parsial terhadap keberhasilan usaha steam motor memiliki pengaruh yang signifikan, hal ini dapat dibuktikan dengan nilai Signifikansi 0.000 berarti lebih kecil dari 0.05 sehingga dapat disimpulkan pada penelitian ini Ho di tolak dan Ha diterima.

3. Hasil pengujian hipotesis variabel harga secara parsial terhadap variabel keberhasilan usaha steam motor memiliki pengaruh yang signifikan, hal ini dapat dibuktikan dengan nilai signifikansi yang lebih kecil dari 0.05 yang berarti pada penelitian ini Ho ditolak dan Ha diterima.

4. Hasil pengujian hipotesis secara simultan antara variabel modal, kualitas pelayanan dan harga didapatkan pengaruh yang signifikan terhadap variabel keberhasilan usaha steam motor dimana nilai signifikansi lebih kecil dari 0.05. adapun persamaan regresi yang didaptkan dari uji regresi linear berganda adalah $\mathrm{Y}=-1.171+0.013 \mathrm{X}_{1}+1.054 \mathrm{X}_{2}-0.832 \mathrm{X}_{3}$ yang menggambarkan bahwa variabel modal dan kualitas pelayanan berpengaruh positif terhadap keberhasilan usaha steam motor dengan ditandai nilai koefisien yang positif sedangkan variabel harga memiliki pengaruh negatif yang ditandai dengan koefisien yang negatif. Sedangkan untuk koefisien determinasi yang dihasilkan dari penelitian ini sebesar 97.3\% yang menggambarkan bahwa ketiga variabel bebas tersebut memiliki pengaruh yang sangat tinggi sedangkan sisanya sebesar $2.7 \%$ adalah pengaruh dari variabel-variabel lainnya yang tidak diteliti pada penelitian ini. 


\section{Saran}

Bagi Pelaku Usaha Steam Motor

Peneliti melihat adanya suatu peluang perbaikan terhadap prosedur kerja yang diamati selama melakukan observasi dilapangan dimana air dari bekas pencucian mengalir terbuang begitu saja ke saluran pembuangan, hal ini dapat di jadikan pertimbangan bagi pelaku usaha untuk menampung air bekas cucian untuk dilakukan proses sedimentasi atau filter sehingga air menjadi bersih dan dapat digunakan kembali namun tentunya metode ini membutuhkan biaya. Sedangkan keuntungan bagi pelaku usaha adalah efisiensi dari air karena air merupakan biaya variabel yang harus dikeluarkan oleh pelaku usaha steam motor.

Yang kedua adalah peluang adanya perbaikan terhadap teknik dan kualitas pelayanan antara satu karyawan dengan karyawan yang lain, dimana terdapat karyawan yang bekerjanya terburu-buru namun tiba-tiba konsumen komplain karena merasa kurang bersih sehingga kemudian karyawan melakukan pencucian kembali, hal ini dapat berdampak terhadap pemborosan dan penurunan kepuasan konsumen. Untuk itu dapat disiasati dengan membuat prosedur atau penyeragaman teknik pencucian dengan cara lebih baik tidak terburu-buru namun hasilnya berkualitas sehingga tidak ada pekerjaan ulang yang berdampak pemborosan selain itu juga dapat menjaga kepuasan konsumen.

\section{DAFTAR PUSTAKA}

Abdul, Kadir Muhammad. 2004. Hukum dan Penelitian Hukum. Bandung. PT. Citra Aditya Bakti

Anwar Prabu Mangkunegara, (2011). Manajemen Sumber Daya Manusia. Bandung. PT. Remaja Rosda Karya

Amirullah, dan Imam Hardjanto, 2005. Pengantar Bisnis. Yogyakarta. Graha Ilmu, Ardi Nugroho, Listyawan. 2011. Pengaruh Modal Usaha. Yogyakarta. Pustaka Pelaja

Az. Nasution. 2004. Hukum Perliindungan Konsumen, Suatu Pengantar. Jakarta. Diadit Media

Bambang Riyanto. 1997. Dasar-dasar Pembelanjaan Perusahaan Edisi Keempat. Yogyakarta. BPEE

Basu Swastha dan Irawan, 2005. Asas-asas Marketing. Yogyakarta. Liberty

Bilson Simamora. 2002. Panduan Riset Perilaku Konsumen. Surabaya. Pustaka Utama. 
Guli dan Uli Wildan: Analisis Keberhasilan...

Buchari Alma. 2002. Manajemen Pemasaran dan Pemasaran Jasa. Bandung. Alfabeta

Djaslim Saladin, 2001, Manajemen Pemasaran, Analisis, Perencanaan, Pelaksanaan dan Pengendalian. Bandung. Lindakarya,

Ghozali, Imam. 2011. Aplikasi Analisis Multivariate dengan program SPSS. Semarang. Badan Penerbit Universitas Diponegoro

Husein Umar. 2011. Desain Peneitian Akuntansi Perilaku. Jakarta. PT Raja Grafindo Persada.

Kotler, Philip and Gary Amstrong. 2012. Prinsip-Prinsip Pemasaran. Jakarta. Erlangga

Maholtra, Naresha K. 2006. Basic Marketing Research: A Decision making Approach. Upper Saddle River. NJ Prentice Hill

Ridwan MBA. 2005. Belajar Mudah Penelitian, Guru dan Konsumen/pelanggan. Bandung. Alfabeta

Shiffman dan Kanuk. 2000. Perilaku Konsumen.Jakarta. PT. Indeks Gramedia

Sugiyono 2012. Metodologi Penelitian Kualitatif, Kuantitatif dan R\&D. Bandung. Alfabeta

Sulastiyono, Agus. 2011. Manajemen Penyelenggaraan Hotel.Seri manajemen Usaha Jasa Sarana Pariwisata dan Akomodasi. Bandung. CV Alfabeta

Tjiptono. 2010. Pemasaran Strategik. Yogyakarta, ANDI

Zeithaml dan Britner.2003. Service Marketing Integrating Customer Focus Across the Firm. Boston. Mc GrowHill/Irwin

Ita Prihatining Wilujeng \& Mochammad Subakti Yusuf. 2011. Faktor-faktor yang dipertimbangkan konsumen dalam penggunaan jasa cuci motor.

Beny Diktus Prima Dwi Candra. 2014. Pengelolaan dan pengembangan Bisnis tempat cuci motor OKE di Surabaya.

Ilham Adi Nugroho, Abu Bakar, Lisye Fitria. 2014. Analisis Kelayakan Usaha Pencucian Kendaraan Bermotor Studi Kasus Purwokerto Timur Jawa Tengah. 
Islamiconomic: Jurnal Ekonomi Islam Vol.8 No.2 Juli - Desember 2017 